\title{
Interactions between Non-oil exports and GDP, FDI in Saudi Arabia 1970-2019: A practical manual ARDL Approach and Toda - Yamamoto Causality
}

\author{
Hassan Tawakol A. Fadol* \\ Associate Professor of Econometrics and Applied Statistic, College of Business Al Jouf University in KSA
}

DOI: $10.36348 /$ sb.2020.v06i06.001 $\quad$ | Received: 12.06 .2020 | Accepted: 20.06 .2020 | Published: 30.06 .2020

*Corresponding author: Hassan Tawakol A. Fadol

Abstract

This paper aims to estimate the effect of Non-oil Exports on GDP, FDI in Saudi Arabian economy for the period between 1970 and 2019. Moreover, it investigates the causal relationship between Non-oil Exports, GDP and FDI applying the ARDL Bound test and Bootstrap Toda - Yamamoto (1995) causality test. The findings of this study suggest that Saudi Arabia followed an export-led growth path and that economic growth has a significant effect on the FDI growth process via export growth channels, in particular, non-oil exports. The overall findings of this study suggest that non-oil exports growth positively affects GDP in the Saudi economy, which in turn supports increased demand for FDI, when all things are considered equal. The results also show that an encouragement of non-oil exports is a necessity for an effective GDP, FDI in KSA. Therefore, in designing policies towards this direction, economy policy response lag need to be taken into. thus we suggest encouraging non-oil export activities in order to stimulate long-term economic growth in KSA this is by supporting increase demand for FDI. A favorable FDI would reduce the cost of production for producers in the non-oil sector. Thus, leading to a growth in the economy.

Keywords: Non-oil exports, GDP, FDI, Stationary, Toda-Yamamoto Test, ARDL, VECM.

Copyright @ 2020: This is an open-access article distributed under the terms of the Creative Commons Attribution license which permits unrestricted use, distribution, and reproduction in any medium for non-commercial use (NonCommercial, or CC-BY-NC) provided the original author and source are credited.

\section{INTRODUCTION}

Over the last few decades, the standard of living in oil-exporter countries has reached a remarkable level, which reflects these countries' total significant economic growth. Standard factors of production of goods and services can affect economic growth, including FDI. By the same token, financial development plays a major role in affecting economic growth in both developing and developed countries. Saudi Arabia, an oil-based economy, has recently devoted more attention to financial sector development. The financial sector in Saudi Arabia has grown rapidly in the last several years, particularly Non oil exports and FDI to achieve economic growth in KSA.

The relationship between economic growth GDP and Non-oil exports has been widely discussed in the literature. Economic researchers have used several different indicators to measure the long-term equilibrium relationship between economic growth GDP and Non-oil exports. In this paper, a wide range of these measurements within Non-oil exports development and their impact on the Saudi Arabian economy at the long term. There also appears to be a problem with the Non-Oil exports data used in these analysis. The only publically-available source of data going back far enough to give a sufficient number of observations is INF organizing. Alhowaish [1], the findings of this study suggest that Saudi Arabia followed an export-led growth path and that economic growth has a significant effect on the import growth process via export growth channels. The empirical results also suggest that imports do not play a role in output or export growth in either the short or long term. The overall findings of this study suggest that export growth positively affects output growth in the Saudi economy, which in turn supports increased demand for imports. Guru-Gharana [2], Using the recently introduced and more suitable ARDL bounds testing approach this study finds that the post liberalization period in India exhibits significantly different characteristics than the pre- liberalization period. If both periods are combined, there is lack of evidence for 
long-run cointegration. In the post liberalization period, however, there is strong evidence of long-run relationship with GDP as the dependent variable.

Indeed, the link between Non-oil exports and GDP is not a new concern. Several empirical studies have been conducted to examine the relationship between the two variables over the past few decades. Yet there seems to be no consensus regarding the direction of causality between Non-oil exports and GDP. For some countries there is a bi-directional causality while for others there is no causality at all. Still for some countries there is a unidirectional causality running from Non-oil exports and GDP while for others there is the opposite causality running from Non-oil exports and GDP. As this paper examines the causality relationship in KSA, we tried to focus on recent studies especially; the focus in this study is on adding and including the FDI variable to explain the balance relationship between the Non-oil exports and GDP via using ARDL and Toda - Yamamoto causality [3].

Although investigating the role of Non-oil exports in GDP is not a new research topic in the field of international trade and economic growth, it remains important to economists and policymakers in formulating a proper growth policy. From the literature survey, there are many studies explaining how Non-oil exports enhance GDP. Motivated by these lacunas in the lack of such studies in KSA, it is needed to establish an empirical study to re-investigate the role of non-oil exports in GDP in KSA using a multivariate framework. This study differs from the previous studies in at least two dimensions. First, besides the ARDL this study also using Toda-Yamamoto to measure the causal relationships between Non-oil exports, GDP and FDI. Second, combining the ARDL test with the VECM model and Toda-Yamamoto [3] Causality to achieve the study goals. The aim of this paper is to examine the relationship between Non-Oil exports and GDP in Saudi Arabia additional to FDI as an influential variable using an Autoregressive Distributed Lag (ARDL) model and Toda - Yamamoto Causality [3].

\section{LITERATURE REVIEW}

Saudi Vision 2030 (SV2030), the strategic roadmap for the future of the Kingdom of Saudi Arabia, aims to decouple the country's economy from its reliance on oil revenues through implementing several economic and social initiatives. The key economic goals of SV2030 announced in 2016 include increasing the private sector's contribution to gross domestic product (GDP) from $40 \%$ to $65 \%$, raising the share of non-oil exports in non-oil GDP from $16 \%$ to $50 \%$, and reducing the unemployment rate from $11.6 \%$ to $7 \%$ by 2030 .

Saudi non-oil economy recorded a 3.3 percent growth at the end of last year, with the overall growth of 0.3 percent during 2019, according to the Saudi General Authority for Statistics. The total economic growth was below expectations, however, the contraction of the oil sector was remarkably noticeable with the non-oil sector increasing its contribution to reaching 3.3 percent, as the Saudi government aims to increase the private sector's contribution to the country's GDP. According to the latest data from the Ministry of Economy and Planning, there has been a sharp rise in the non-oil exports in 2019. In the first quarter, non-oil exports reached a US\$ 3.13 billion (SR 11.73 billion), up some $37 \%$ from US\$ 2.28 billion (SR 8.55 billion) in the same quarter of year 2018. The Ministry expects this trend to continue, particularly as high levels of investment are currently being channeled into the industrial sector.

Various studies have been conducted to study the relationship between non-oil exports and economic growth in the literature. The result of these studies varies from one to the other; owing to the difference in methodologies and time frames as well as the variables captured in the models. Therefore, in the present study we employ the more robust technique developed by Pesaran and Shin [4, 5], and Pesaran et al., [6], and apply multivariate framework by including Non-Oil exports, GDP, and FDI. These state-of-the-art techniques have not been employed in the KSA context to study the relationships among these variables. Although the ample number of studies focused on causality between Non-oil exports and GDP, the consensus has not been reached yet. Thus, more research should be done to establish the direction of causality between the variables.

\section{DATA, MODEL AND METHODS Data and Empirical Modeling}

Data were collected the annual data for non-oil exports, GDP and FDI and from the International Monetary Fund. This study covers the annual sample period from 1970 to 2019. The descriptive statistics show that the standard deviations differ among variables. In addition, at the $5 \%$ significance level, we find that all variables are normally distributed (JarqueBera, Skewness and Kurtosis statistics) See Table-1. 
Hassan Tawakol A. Fadol., Sch Bull, June., 2020; 6(6): 139-145

Table-1: Descriptive Statistics

\begin{tabular}{|l|l|l|l|}
\hline Statistics & NOE & GDP & FDI \\
\hline Mean & 120124058821.1863 & 6248396260.924869 & 262681065971.759 \\
\hline Median & 62431688637.29755 & 874450102.521353 & 155950708152.6145 \\
\hline Maximum & 399419733333.3329 & 39455863929.3334 & 766350347333.333 \\
\hline Minimum & 2731777777.77778 & -3732394367.24856 & 5377333333.33333 \\
\hline Std. Deviation & 116249445647.022 & 11082189552.44239 & 242696763626.1531 \\
\hline Skewness & 1.100208075358777 & 1.754655550165247 & 1.0329836795287 \\
\hline Kurtosis & 2.883656753798241 & 5.039691293436434 & 2.562814741363974 \\
\hline Jarque Bera & 10.11534789015713 & 34.32417702379836 & 9.290316831373444 \\
\hline
\end{tabular}

\section{Econometric Methodology}

As In time series econometrics, the starting point is to study the time series properties of the variables under consideration to avoid any spurious relationships between them. If the time series properties of the variables are satisfied, then possible long-term relationships or co-integration are likely to exist, the analytical procedure adopted in this study include: the specification of the empirical models, the concept of Toda-Yamamoto causality within a ARDL framework, Vector Error-Correction Modeling (VECM). The baseline empirical model is specified to capture the hypothesized relationship among the core variables namely: non-oil exports, GDP and FDI. In doing this, the endogenous growth theory is a useful guide. This theory emphasizes the role of exports in determining long-run growth via a higher rate of technological innovation and dynamic learning from abroad [7, 8].

Figure-1 shows that both foreign direct investment and Non-Oil Exports increased during the study period. It was found that during the period 1990 and 2019 the increase and change was a quick and simple. The researcher finds that the change is consistent for all variables during this period and Saudi GDP product is increasing during the study period because the increase in the rates of FDI, non-oil exports and other variables.
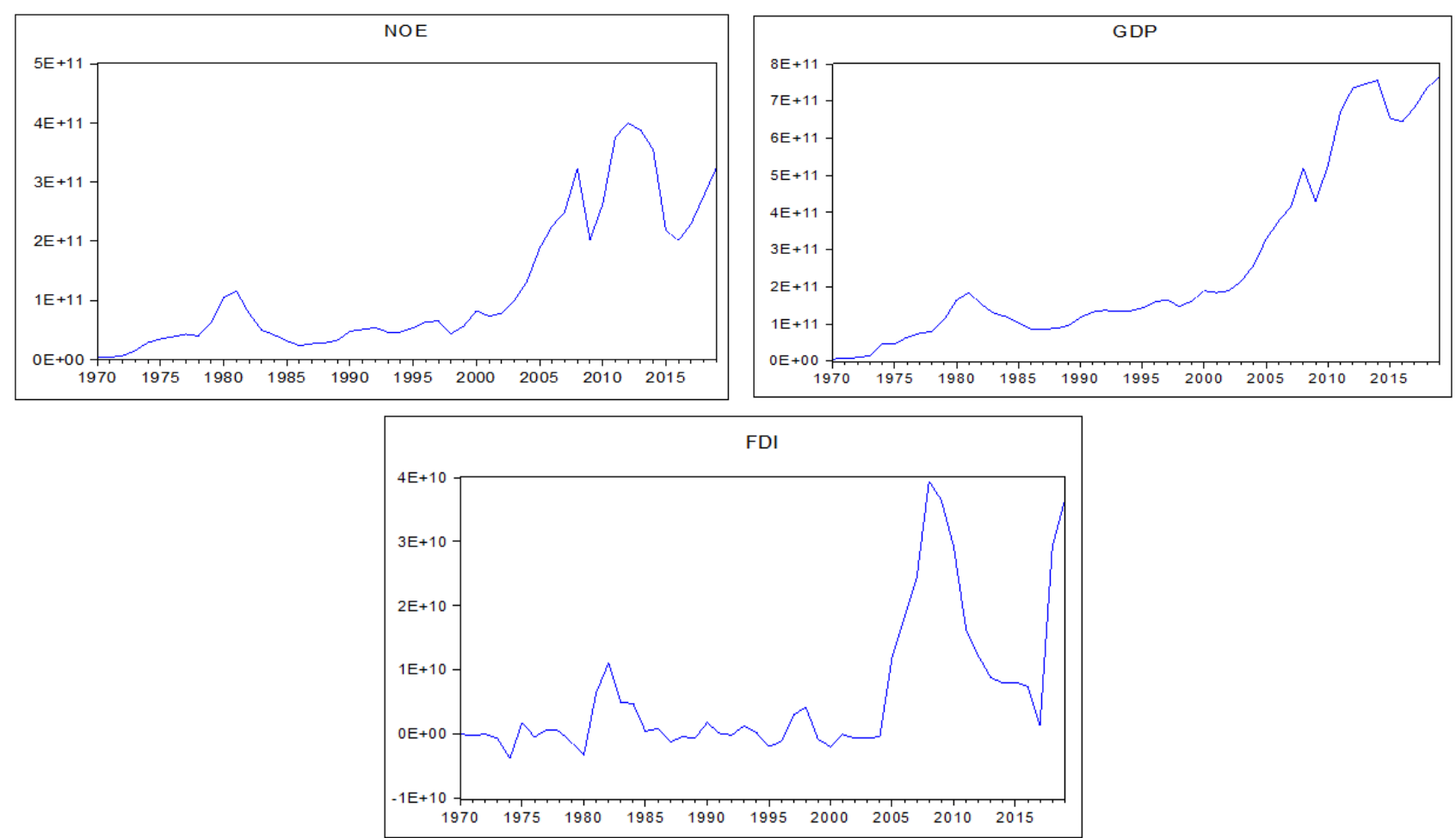

Fig-1

\section{Autoregressive Distributed Lag Models (ARDL)}

The study draws on the ARDL approach that is proposed by Pesaran et al., [9] and subsequently it was modified by Pesaran, Shin and Smith by introducing the bounds testing approaches [9]. We select this technique for two main reasons: First, it is effective in executing the short- and long-term relationships between the different variables that do not have the same order of integration - provided that such variables are stationary in level; I (0), and/or they are stationary in the first difference; I (1). Second, the ARDL approach can remove the problems associated with omitted variables and auto correlation. The model used for the application of the ARDL approach: 


$$
\Delta \mathrm{NOE}_{\mathrm{t}}=\alpha+\Sigma \beta_{\mathrm{i}} \Delta \mathrm{NOE}_{\mathrm{t}-1}+\Sigma \lambda_{\mathrm{i}} \Delta \mathrm{GDP}_{\mathrm{t}-\mathrm{i}}+\varphi \mathrm{NOE}_{\mathrm{t}-1}+\delta \mathrm{FDI}_{\mathrm{t}-1}+\eta_{\mathrm{t}}
$$

Where,

\author{
NOE $=$ Non-oil exports \\ $\mathbf{G D P}=$ Gross domestic product \\ FDI= Foreign Direct Investment \\ $(\boldsymbol{\alpha}, \boldsymbol{\beta}, \boldsymbol{\lambda}, \boldsymbol{\varphi}, \boldsymbol{\delta})=$ Coefficients of variables \\ $\Delta=$ The first difference for the variables \\ $\eta=$ Random error
}

Although ARDL co-integration technique does not require pre-testing for unit roots, to avoid ARDL model crash in the presence of integrated stochastic trend of I(2), we are of the view the unit root test should be carried out to know the number of unit roots in the series under consideration. This is presented in the next section.

\section{Vector Error Correction Models (VECM)}

The VECM approach provides a systematic way to treat non-stationary variables in a simultaneous equation system, thus addressing the issues of simultaneity and non-stationarity. A brief discussion of these issues is followed by a description of the general form of the VECM, and included variables Non-Oil Exports, GDP and FDI of the Saudi economy during the period which is 1970-2019. Causality inferences in the multi-variate framework are made by estimating the parameters of the following VECM equations.

$$
\left[\Delta N o n-O i l E=\alpha+\sum_{i=1}^{m} \beta i \Delta N o n-O_{i l E}-i+\sum_{k=1}^{0} \delta \Delta G D P+\sum_{l=1}^{p} \zeta \Delta F D I+\theta Z_{t}-1+\varepsilon t\right]
$$

Where (Non-OilE) is the Non-Oil Exports, (GDP) and (FDI) Foreign Direct Investments denote respectively, and $\mathrm{zt}-1$ is the error-correction term which is the lagged residual series of the cointegrating vector. The error-correction term measures the deviations of the series from the long run equilibrium relation

\section{Toda - Yamamoto Causality [3]}

The Toda and Yamamoto [3] method of Granger causality test is relatively more efficient in small sample data sizes and is particularly appropriate for time series for which the order of integration is not known or may not be necessarily the same, or the order of integration is more than two. Another advantage of this procedure is that it does not require the pretesting of the time series for cointegration properties so long as the order of integration of the process does not exceed the true lag length of the model. Toda and Yamamoto [3] methodology of Granger causality test by directly performing the test on the coefficients of the levels VAR, minimises the risk associated with possibly wrongly identifying the orders of integration of the series and the presence of cointegration relationship $[10,11]$.

\section{EMPIRICAL RESULTS AND DISCUSSION Unit Root and Co-integration Tests}

Before I proceed with the ARDL bounds test, I tested for the stationarity status of all variables to determine their order of integration. This is to ensure that the variables are not $\mathrm{I}(2)$ stationary so as to avoid spurious results. According to Ouattara [12] in the presence of $\mathrm{I}(2)$ variables the computed F-statistics provided by Pesaran et al., [6] are not valid because bounds test is based on the assumption that the variables are $\mathrm{I}(0)$ or $\mathrm{I}(1)$. Therefore, the implementation of unit root tests in the ARDL procedure might still be necessary in order to ensure that none of the variable is integrated of order 2 or beyond. I employed ADF dickey-fuller test to obtain the order of integration of each variable as results shown in Table-2.

Relying on the results of the conducted unit root tests, we conclude that the studied time series are of same order of integration. According to the results of the ADF test, we have variables (GDP, FDI and NonOil Exports) stationary in the first difference I (0).

Table-2: Results of Unit-Root Test (ADF)

\begin{tabular}{|l|l|l|l|l|}
\hline Variables & Level ADF test statistics & Lags & First Difference ADF test statistics & Lags \\
\hline NOE & -0.736134 & 1 & $-5.702097 *$ & 1 \\
\hline GDP & 0.849850 & 1 & $-5.531369 *$ & 1 \\
\hline FDI & -1.085793 & 1 & $-5.579721 *$ & 1 \\
\hline
\end{tabular}

Results of ADF unit root tests shown in Table1, indicate that the hypothesis that the time series LNon-Oil Exports, LGDP and LFDI are stationary in the first difference can be accepted. Relying on the results of the conducted unit root tests, we conclude that the studied time series are of same order of integration. According to the results of the ADF, tests, we have all variables (Non-Oil Exports, GDp and FDI) stationary in the first difference I (0). has the order of integration I (1) based on the results of the ADF tests. 
Hassan Tawakol A. Fadol., Sch Bull, June., 2020; 6(6): 139-145

\section{ARDL Bound Test Critical Values}

Maximum 4 lag is used to carry out the find cointegration relationship between variables. Minimum Akaike Information Criteria (AIC) and Schwarz Bayesian Information Criteria (SBC) are used to determineoptimal lag length. $\operatorname{ARDL}(4,1,0)$ is the optimal model for the cointegration analysis, and there is no autocorrelation problem in this estimated model. Besides, the calculated F-statistic of the model is founded as 44.38286 .

Table-3: ARDL Bound Test Critical Values

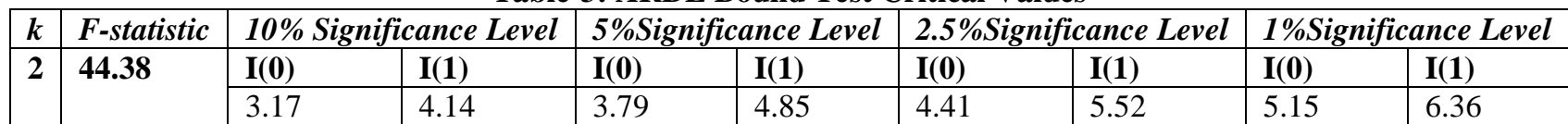

Note: $k$ denotes the independent variables in the model (GDP, FDI).

The long-run co-integration relationship between Non-Oil Exports, GDP and FDI exists. So, the long-run coefficients of the model should be estimated. ARDL $(4,1,0)$ is the optimal lag lengths for the long run model, and its estimation results are showed in Table-4. There is no autocorrelation, heteroskedasticity and normality problem in the long-run estimation. Non-Oil Exports, GDP and FDI is calculated as 1.00, and it is statistically significant at $10 \%$. According to long-run estimation results, GDP, FDI affects Non-Oil Exports positively.

Table-4: Long-Run Estimation Results

\begin{tabular}{|l|l|l|l|}
\hline Independent Variables & Coefficients & Probability \\
\hline GDP(-1) & $0.373949^{* *}$ & 0.0000 \\
\hline FDI(-1) & $0.443556^{*}$ & 0.0148 \\
\hline C & -5.992419 & 0.2012 \\
\hline Descriptive Statistics & 0.98 & Heteroskedasticity Breusch-Pagan-Godfrey & $0.88[0.52]$ \\
\hline R2 & 0.97 & Normality (Jarque-Bera) & $1.61[0.65]$ \\
\hline Adjusted R2 & $4.92[0.42]$ & Durbin-Watson stat & 1.44 \\
\hline Autocorrelation (LM) & L & L & \\
\hline
\end{tabular}

Note: $* *$ and $*$ denote statistical significance at the $1 \%$ and $5 \%$ levels, respectively. Figures in the square brackets are pvalues

\section{VECM Short Run Coefficients}

After estimating the long-run model, an VECM should be estimated. ARDL $(4,1,0)$ is the optimal lag lengths for the VECM, and its short-run estimation results are displayed in Table (5). This model also passed all the diagnostic tests such as autocorrelation, heteroskedasticity, and normality.
According to results, GDP, FDI affects Non-Oil Exports in the current year positively as expected. However, its effects are negative in 3 st and 5thlags. The coefficient of ECT is estimated as -0.43 , it is negative and statistically significant as expected. This result indicates that $43 \%$ of disequilibrium is corrected in one year.

Table-5: VECM Short Run Coefficients

\begin{tabular}{|c|c|c|c|}
\hline Variables & Coefficients & Standard error & t-ststistic \\
\hline $\mathrm{D}(\mathrm{NOE}(-1))$ & $1.347914 *$ & 1.76253 & 1.76253 \\
\hline $\mathrm{D}(\mathrm{NOE}(-2))$ & $-0.927426^{* *}$ & 0.71466 & -1.26533 \\
\hline $\mathrm{D}(\mathrm{GDP}(-1))$ & $-1.049254 * *$ & 0.71901 & -1.44199 \\
\hline $\mathrm{D}(\mathrm{GDP}(-2))$ & $0.818273 *$ & 0.98575 & 1.11774 \\
\hline $\mathrm{D}(\mathrm{FDI}(-1))$ & $-1.248687^{*}$ & 1.58745 & -1.24413 \\
\hline $\mathrm{D}(\mathrm{FDI}(-2))$ & $1.864741^{*}$ & 1.48301 & 1.15371 \\
\hline $\begin{array}{l}\mathrm{R}^{2}=0.67 . \\
\mathrm{R}^{-2} 0.65 \\
\text { Durbin Wats } \\
\text { Lagrange mu } \\
\text { Heteroskedas } \\
\text { Breusch-Paga } \\
\text { Normality Ja } \\
\text { *Indicates sig } \\
\text { **Indicates s } \\
\text { VECM: Vect }\end{array}$ & $\begin{array}{l}t=1.69 \\
\text { er }(\text { Lag } 1)=(0.2 \\
\text { Breusch-Paga } \\
\text { dfrey test }=(0 . \\
\text { Bera test }=(0.7 \\
\text { ant at } 1 \% ; \\
\text { cant at } 5 \% ; \\
\text { or correction r }\end{array}$ & $\begin{array}{l}(\operatorname{Lag} 2)=(0.3515 \\
\text { dfrey }=0.41 \\
)\end{array}$ & $g$ g 3$)=(0.7718)$ \\
\hline
\end{tabular}


The results show that non-oil exports have long run relationship with GDP, FDI. Further, GDP, FDI positively and significantly affect Non-oil exports in the short run as well as in the long run.

\section{Toda - Yamamoto (1995) Causality Test [3]}

After establishing that a co-integrated relationship between Non-oil exports, GDP and FDI, the study proceeded to also test for Toda - Yamamoto causality as introduced by Toda - Yamamoto [3]. Modified Wald test (MWALD) for the causality test is used as proposed by Toda and Yamamoto [3] which avoids the problems associated with the ordinary
Granger causality test by ignoring any possible nonstationary or co-integration between series when testing for causality. The Toda and Yamamoto [3] approach fits a vector autoregressive model in the levels of the variables thereby minimizing the risks associated with the possibility of faulty identifying the order of integration of the series [11].

So this final stage of our empirical analysis, we test for the causal relationship among our variables of interest (Non-oil exports, GDP and FDI) according to Toda - Yamamoto causality test [3].

Table-6: Toda - Yamamoto (1995) Causality Test [3]

\begin{tabular}{|l|l|l|}
\hline Null Hypothesis: & Wald test statistic & P-value \\
\hline D(NOE) does not Cause D(GDP) & 18.03599 & $0.0001^{* *}$ \\
\hline D(GDP) does not Cause D(NOE) & 7.140083 & $0.0282^{*}$ \\
\hline D(NOE) does not Cause D(FDI) & 3.986331 & 0.1363 \\
\hline D(FDI) does not Cause D(NOE) & 5.343433 & $0.0491^{*}$ \\
\hline D(GDP) does not Cause D(FDI) & 2.083446 & 0.3528 \\
\hline D(FDI) does not Cause D(GDP) & 2.772820 & 0.2500 \\
\hline
\end{tabular}

From Table-6, we conclude that for there is a bidirectional causal effect between Non-Oil Exports and GDP in KSA. Thus, at 5\% level of significance, NonOil Exports has a causal effect on GDP. And GDP and inflows of foreign direct investment, there is an independent causal relationship between them. Thus, neither is there a causal effect flowing from GDP to inflow of FDI nor is there a causal effect moving from inflow of FDI to GDP at 5\% level of significance. Finally, there is a one-way causal relationship between foreign direct investment and non-oil exports.

\section{CUSUM and CUSUMSQ (ARDL 4, 1, 0):}

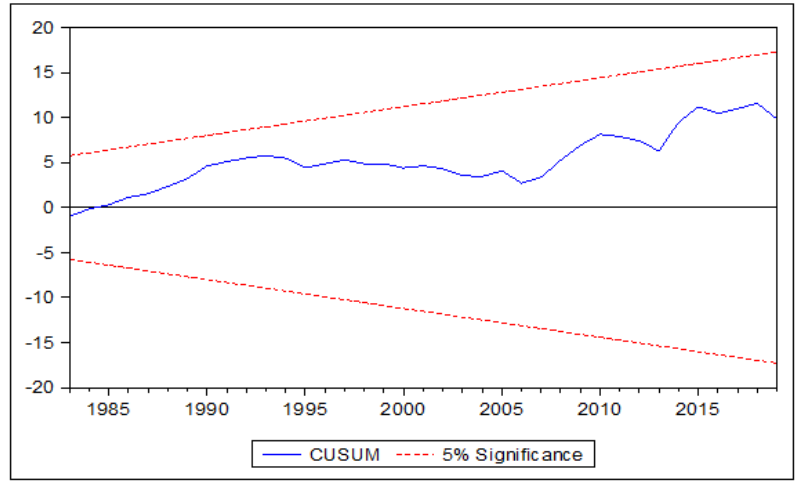

Fig-2: CUSUM

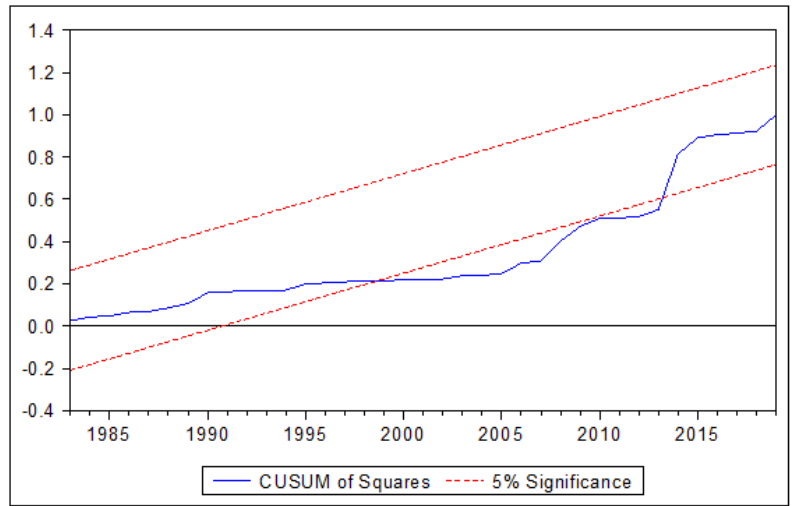

Fig-3: CUSUMSQ

The stability of the long run parameters were tested using the cumulative sum of recursive residuals (CUSUM) and CUSUM of recursive squares (CUSUMSQ). The results are illustrated in Figures 2 and 3 . The results fail to reject the null hypothesis at 5 percent level of significance because the plot of the tests fall within the critical limits. Therefore, it can be realised that our selected ARDL $(4,1,0)$ model is stable.

\section{CONCLUSION}

Conclusion The paper discussed measuring the relationship between non-oil exports, GDP, and FDI in KSA during the period 1970-2019. The long-run relationships between these variables are intriguing and are of acute interest to policy makers. Using the ARDL bounds-testing approach of co-integration, suggested by Pesaran et al., [6], together with the VECM method, and Toda - Yamamoto 1995 Causality, the study reaches the following conclusions. The ARDL cointegration results showed that non-oil exports, GDP, and FDI are co-integrated, indicating the presence of a 
long-run equilibrium relationship between them. The Toda - Yamamoto [3], VECM results showed the presence of bidirectional causality between non-oil exports, GDP, and a unidirectional causality from FDI and non-oil exports direct investment. A policy implication of this study is that non-oil exports can be considered to be the best policy variable to predict both GDP and foreign direct investment in KSA. If policymakers want to maintain sustainable economic growth and high foreign direct investment, they must focus on building non-oil exports in the economy in the longer term. Such a policy could be also supported by infrastructure policy restructuring, especially in the non-oil exports sector, in line, for instance, with the suggestions of Pradhan and Bagchi [13]. This study would be a valuable addition to the growing body of empirical literature on relationship between macroeconomic variables, besides being useful to policy makers, investment community. They should watch out for impact of GDP, FDI in non-oil exports, and oil prices on volatility in the markets.

\section{ACKNOWLEDGMENT}

We would like to thank the anonymous reviewers for their valuable comments and suggestions on the earlier draft of this research. We would also like to thank Dr. Abdalla Elmolhim for knowledge-sharing and Dr. Tarig Elrasheed for sharing his E-views9 programming codes. Any remaining errors or omissions are the responsibility of the authors.

\section{Cancelation}

This study examines the long-run relationship between Non-Oil Exports, GDP and FDI, in KSA for the time period 1970 to 2019 . In order to assess the long-run relationship, the study used the tests Evidence from (VECM) and (ARDL) and evaluation from Toda Yamamoto Causality test [3].

\section{REFERENCES}

1. Alhowaish, A. K. (2014). Exports, imports and economic growth in Saudi Arabia: An application of cointegration and error-correction modeling. Pensee Journal, 76(5), 120-134.

2. Guru-Gharana, K. K. (2012). Relationships among export, FDI and growth in India: an application of auto regressive distributed lag (ARDL) bounds testing approach. Journal of International Business Research, 11(1), 1.

3. Toda, H. Y., \& Yamamoto, T. (1995). Statistical inference in vector autoregressions with possibly integrated processes. Journal of econometrics, 66(1-2), 225-250.

4. Pesaran, M. H., \& Shin, Y. (1995). Autoregressive distributed lag modeling approach to cointegration analysis. DAE Working Paper Series, No. 9514, Department of Economics, University of Cambridge.

5. Pesaran, M. H., \& Shin, Y. (1998). An Autoregressive distributed lag modeling approach to cointegration analysis. In Storm, S. (Ed.) Econometrics and Economic Theory in the 20th Century: The Ragnar Frisch Centennial Symposium, Cambridge University Press. 1-31

6. Pesaran, M. H., Shin, Y., \& Smith, R. J. (2001). Bounds testing approaches to the analysis of level relationships. Journal of applied econometrics, 16(3), 289-326.

7. Romer, P. M. (1986). Increasing returns and longrun growth. Journal of Political Economy, 94: 1002-1037.

8. Lucas, R. E. (1988). On the mechanics of economic development. Journal of Monetary Economics, 22(1): 3-42

9. Pesaran, M., Shin, Y., \& Smith, R. (1986). Testing for the Existence of a Long-run Relationship. Faculty of Economics, University of Cambridge; No.9622.

10. Galies, D. (1997). Causality between the measured and underground economies in New Zealand. Applied Economics Letters, 4(1), 63-67.

11. Mavrotas, G., \& Kelly, R. (2001). Old wine in new bottles: Testing causality between savings and growth. The Manchester School, 69, 97-105.

12. Ouattara, B. (2004). Modelling the long run determinants of private investment in Senegal (No. 04/05). Credit Research Paper.

13. Pradhan, R. P., \& Bagchi, T. P. (2013). Effect of transportation infrastructure on economic growth in India: the VECM approach. Research in Transportation Economics, 38(1), 139-148. 